\title{
Supply Chain Analysis of Shallots Through Relational Approach (Research on Shallot Farmers in 4 District, East Java)
}

\author{
${ }^{1}$ Agatha Christy Wahyono and ${ }^{2}$ Kusdi Rahadjo \\ ${ }^{1,2}$ Business Administration Faculty, Brawijaya University
}

\begin{abstract}
Purpose - This research aims to examine the effect of relational capital to supply chain integration and supply chain responsiveness.

Design/methodology/approach - This research uses explanatory research with a quantitative approach. The object of this research was in four districts of East Java at Nganjuk, Kediri, Malang, and Probolinggo which are the centers of onion production that have similar environmental conditions. The sampling method in this research used multistage proportional random sampling with 200 respondents as a sample of this research. Data analysis uses the path analysis method by software SPSS 23 .
\end{abstract}

Findings - The results show that the relational capital has a positive and not significant effect on the supply chain integration and relational capital has a positive and significant effect on the supply chain responsiveness.

Practical Implications - Supply chain responsiveness is greatly affected by the relational capital but not with the supply chain integration.

\section{Originality/value -}

Keywords Agroindustry, Relational Capital, Shallot, Supply Chain Integration, Supply Chain Responsiveness

Paper Type Research paper (case study)

Keyword: Agroindustry, Relational Capital, Shallot, Supply Chain Integration, Supply Chain Responsiveness

Vol. 28, No. 01 April 2020

(C) Centre for Indonesian Accounting and Management Research Postgraduate Program, Brawijaya University 


\section{INTRODUCTION}

Supply chains are important activities in various industrial sectors including in the agricultural sector that carry out the distribution of supply of goods or services from the place of origin to the place of buyers or customers (Assauri, 2011: 280). Supply chains are also activities that integrate economic, social and environmental aspects, with the aim that the managed supply chain can meet consumer desires (responsiveness) in terms of quality, quantity, type, place and time delivery in a sustainable manner (Cuthberson, 2011; Ageron et al., 2011; Seuring 2012).

Development of the theory and practice of agribusiness and agroindustry supply chain management in developing countries related to the implementation of free trade. Woods (2004) states that the goal of developing supply chain management in developing countries is to build the capacity of local producers so that they are able to produce products that meet the needs of the domestic and export markets. Another goal is to help farmers in developing countries to take advantage from growth opportunities in world food consumption needs.

One of the agricultural commodities that gets special attention from the government in order to increase production and domestic competitiveness is shallots. Shallot is a plant that attracts the attention of many parties both from within and outside the country because the number of devotees is high enough to have quite a lot of competitors. However, there are some significant problems in the shallot supply chain. The onion supply chain is still quite long, as seen in figure 1.1. According to Gunawan (2014), the longer the distribution chain of a product, the higher the price of the product. The results of research conducted by Rasoki et al. (2016) showed that the supply chain system that occurred in the marketing of onions is not efficient. For this reason, it is necessary to implement supply chains that are well integrated so that the distribution system can run more effectively and efficiently. 


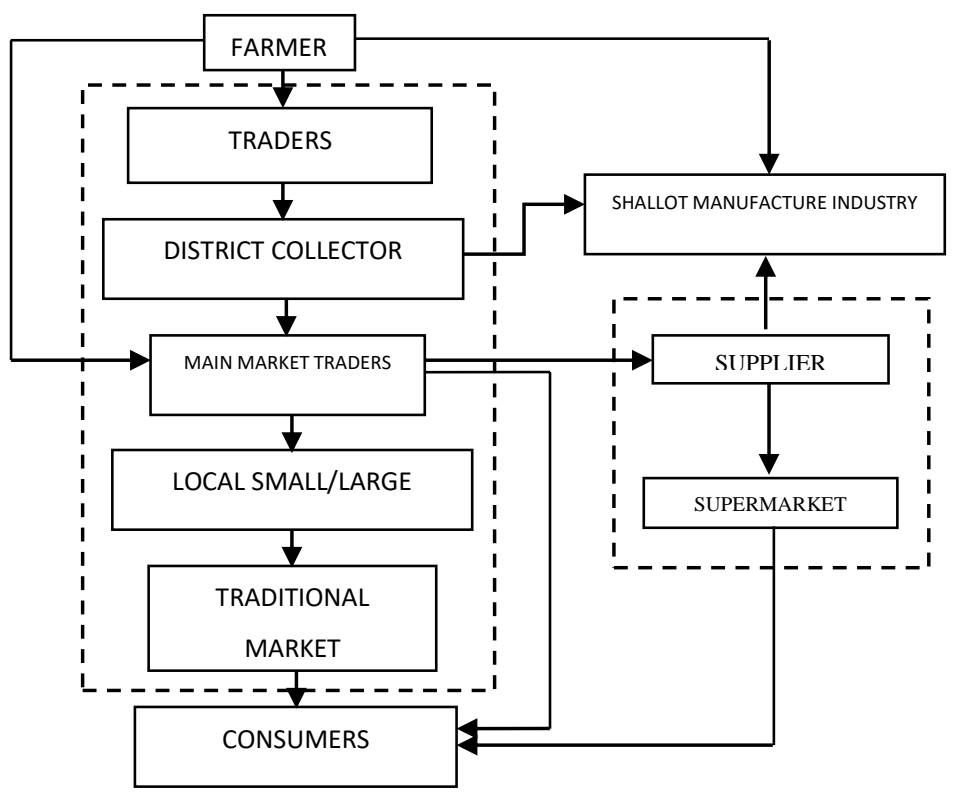

Source: Development Financial AccessDepartment and BI SME, 2013

Figure 1.1 Shallot Distribution Line

In addition, other issues have led to the lack of competitiveness of the commodity onion that is not yet created a competitive advantage is the low quality of farmers human resources (HR). The low level of farmer human resources has made it difficult for farmers to absorb knowledge and skills in terms of business productivity, which affects the level of productivity. This also affects the response of farmers to increase productivity using technology. The current technological developments can be utilized in the agricultural sector to increase agricultural productivity.

Productivity can be said is a manifestation of all the factors related to soil and non-soil affect crop yields based on economic considerations (Nurmala, 2012). Whereas according to Mubyarto (1989) more specifically discusses the productivity referred to in the agricultural sector, namely productivity occurs because of the influence of resources, capital and labor.

Vol. 28, No. 01 April 2020

(C) Centre for Indonesian Accounting and Management Research Postgraduate Program, Brawijaya University 
Table 1. Shallot Productivity in East Java Province 2013-2017

\begin{tabular}{ccc}
\hline Year & Productivity(Tons/Ha) & growth $(\%)$ \\
\hline 2013 & 9.34 & \\
2014 & 9.57 & 2.40 \\
2015 & 9.00 & -6.33 \\
2016 & 8.42 & -6.89 \\
2017 & 8.24 & -2.18 \\
\hline
\end{tabular}

(Source: Central Bureau of Statistics and Horticulture General Directorate)

The Indonesian government continues to strive to increase productivity in the agricultural sector and overcome various problems that occur. The aim is for shallot products to have a competitive advantage and reliable competitiveness compared to its competitors. However, productivity in shallots in Indonesia has decreased significantly in 2015 until 2017. This is shown in table 1.1. The productivity of shallots, especially in the East Java Province, has decreased significantly from 2015 to 2017 . The decline in shallot productivity has caused a low competitive advantage and competitiveness of shallots.

The weakness of human resources in the agricultural sector also causesasymmetric informationreceived by farmers. Agency Theory reveals that there are two different interests in the company where each party strives to achieve the desired prosperity, so information asymmetry arises between partners and business actors (Sefiana, 2009). Farmers are disadvantaged by the existence of partner because the yield of the products that are planted can get a greater profit but this does not occur because of the price play of the partner and the bargaining power of the farmers. to meet needs in production and daily needs (Fuad, 2015). This has led to the lack of good relations between farmers and their partners, resulting in a decrease in the productivity of shallot products. This is evidenced by several previous studies which said that the relationship between farmers and its partners was still not going well (Fuad, 2015; Isna, 2014; Rustinsyah, 2011). Therefore, an integrative supply chain is needed so as to minimize asymmetric informationthat occurs to farmers, improve the relations of farmers and partners, and form responsive supply chains. 
Supply chains are a series of activities (physical and decision making) that are related to the flow of material and information, as well as the flow of money and property rights, which cross the boundaries of each supply member (Van der Vorst, 2004). The supply chain concept discusses how to integrate all activities of an organization or individual involved, so that it can be effective and efficient in delivering goods or services to its customers (McKellar 2006; Anatan and Ellitan 2008).

Integration aims to provide added value to end consumers and producers or suppliers also benefit (Marshall et. al., 2008). Another goal of integration in the supply chain is to get the movement of products, information, money and decisions through effective and efficient business coordination with customers at low cost without delay (Frohlich and Westbrook, 2001; Wong, et al., 2011). Lack of integration in the supply chain can cause serious problems such as increasing costs, delaying procurement, reducing product quality and accurate inaccuracies in product and information forecasts, which can harm the focus of the organization and all its supply chain partners, with deteriorating customer satisfaction. This can have an effect on the performance of a business / business / company.

According to Ghai (2012), integrating supply chains can improve competitiveness through the following benefits, providing information to farmers to invest according to market needs and obtain better prices. Another benefit is helping our practice to obtain good results and quality, reducing damage through better post-harvest technology, getting better prices than passing sorting and assessing, reducing ineffective suppliers in long-lived, commodity marketing because it requires processing and packaging, help market-oriented farmers, and improve relations between farmers and industry. According to Firdaussy (2012), market forces possessed by traders can affect the asymmetric price of goods. Asymmetric price transmission can also oppose government policies that intervene more at farmers' prices than prices on the market. However, there is asymmetry, which is the difference that affects the increase and decrease in prices in farmers towards distributors and retailers (Jezghani et al. 2011). This requirement implies paying attention to policies that can reduce farmers' production costs, in consumer protection.

The responsive supply chain serves to identify the extent to which collaborative practices of companies in the supply chain network are able to respond to consumer demand which includes a reduction in waiting time, flexibility in accommodating demand, and sensitivity to consumer demand. 
Ibrahim and Hamid (2012) mention sub-construction for responsive supply chains including responsiveness operating systems, responsive to logistics processes and supplier network responsiveness. Responsive operating system capabilities of the company's manufacturing system to overcome changes in customer demand. This includes manufacturing and operating services, networks. Supplier responsiveness is the ability of the company's main supplier to change the company's request address. The key to responsiveness is the responsiveness and flexibility of upstream and downstream partners of the company. Lumnus, Duclos and Vokurka (2003) showed that responsive on every Ranai supply companies are an integral component of the supply chain responsiveness. Responsiveness logistics process is the outbound capability of the company's transformation, distribution and warehousing system due to changes in customer requests regarding the address of the request.

To be able to overcome these problems, effective and efficient supply chains are needed if they are supported by several supporting factors such as human resources (Barney, 1991; Mata, Fuerst, \& Barney, 1995; Peteraf, 1993; Wernerferlt, 1984). Good human resources need to be established so as to improve supply chain performance that is well integrated and more responsive (Flynn et al., 2010). Based on Flamholtz's theory (1973), it was concluded that intangible assets such as human resources have an important role in the agricultural sector to create appropriate relations and increase responsiveness to the needs of customers and partners in the agricultural sector. Empirical findings from Schoenherr and Swink (2012) reinforce the importance of relational capital or relational capital to create an integrative supply chain.

Moeheriono (2012: 306) defines relational capital as a harmonious relationship that the company has with its partners, both from reliable and quality suppliers, coming from loyal customers and satisfied with the service of the company concerned, originating from the company's relationship with government and the surrounding community. According to Welbourne (2007) relational capital is an intangible asset based on developing, maintaining and maintaining high-quality relationships with any organization, individual or group influences that affect business performance including: customers, suppliers, employees, government, partners, other stakeholders and sometimes to competitors.

Research conducted by Cousineau et al in Setiawan (2005) said that in the presence of integrative supply chain management that involved complex relational capital between companies and suppliers and buyers, if managed Vol. 28, No. 01 April 2020

(C) Centre for Indonesian Accounting and Management Research Postgraduate Program, Brawijaya University 
properly can increase efficiency in business activities so that profits increase and provide satisfaction for all parties. Therefore, it can be said that with the implementation of an integrative supply chain, efficiency in the agricultural sector has increased. The integrative supply chain that is applied effectively and efficiently is able to realize supply chain responsiveness activities (Marimin and Maghfiroh, 2010). Thatee (2007) states that supply chain responsiveness can reduce costs, reducing costs will create a competitive advantage in the agricultural sector.

the purpose of this research Include:

1. Analyzed the effect of relational capital on integrative supply chains.

2. Analyzed the effect of relational capital on supply chain responsiveness.

\section{RESEARCH METHODS}

\subsection{Research Type}

The type of research in this research is explanatory research with a quantitative approach. Explanatory research is a type of research that emphasizes causality or causality between two or more variables that influence each other. The approach in this research used a quantitative approach. According to Sugiyono (2010: 14), a quantitative approach is an approach based on a positivist philosophy, used to examine certain populations or samples, sample collection techniques are generally done randomly, data collection uses research instruments, data analysis is quantitative statistics with the aim of testing hypotheses previously set.

The research method used in this research is to use the survey method. The survey method is used in this research because this research uses a questionnaire as an instrument for a particular sample to obtain data to be analyzed as hypothesis testing.

\subsection{Research Location}

The location of the research is in Nganjuk Regency, Probolinggo Regency, Kediri Regency and Malang Regency. The selection of research locations is based on the consideration that the four regencies are the four largest red onion producing districts in East Java Province, so researchers assume that the sample chosen as respondents is quite representative and can answer research problems for data analysis and answer the research hypothesis. 


\subsection{Population}

The population in this research are all farmers who are members of the Combined Farmers Group in the villages that have been selected in each Regency. The total population of secondary data obtained is 2390 shallot farmers, with details:

Table 2 Number of Farmers in the Four Districts that Are Research Sites

\begin{tabular}{cc}
\hline Regions & Population \\
\hline Nganjuk Regency & 1256 \\
KediriRegency & 597 \\
Malang Regency & 297 \\
Probolinggo Regency & 240 \\
\hline Total & 2390 \\
\hline
\end{tabular}

(Data source: Food and agriculture security service, 2018)

To determine the population in this research, researchers chose a shallotproducing sub-district in each Nganjuk Regency, Kediri Regency, Malang Regency and Probolinggo District which is the largest shallot producing center in East Java, has the largest harvested land in East Java, has the similarity of environmental conditions is located at an altitude of 150-600 m above sea level, soil type grumusol or margalit and the average daily temperature is $31^{\circ} \mathrm{C}$. Then through the Subdistrict, the researcher obtained a shallot planter village to become the object of research in each Regency. In this research, the population is all farmers who are members of the Combined Farmers Group who purchase drugs, seed onions and sell their crops to collectors, traders in villages that have been selected in each district.

\subsection{Samples}

Vol. 28, No. 01 April 2020

(C) Centre for Indonesian Accounting and Management Research

Postgraduate Program, Brawijaya University 
The sampling method in this research used multistage proportional random sampling. Multistage is sampling in two stages or more (Nazir, 2014: 243). This research used multistage because researchers cannot identify population easily and the population is very large. Nazir (2014: 247) argues that the proportional random sampling method is a sampling technique where all members of the population have the same opportunity to be selected as samples and consider the size of the sample based on the size of the population.

Having difficulties in identifying a very large population, the sample size in this research was determined using the Roscoe formula. Roscoe's formula is at least 10 times the number of variables studied and multiples thereof (Sugiyono, 2010: 124) with a degree of error of 5\%. Based on the calculation of the roscoe formula, it was obtained the size of up to 200 respondents. This research used 50 times the number of variables, namely $50 \times 4=200$ respondents.

\subsection{Sampling Technique}

The sampling technique is done in various stages (multistage). The same stages are carried out in each selected Regency. The first stage until the last stage is explained as follows:

1. Four districts were selected as centers of shallots in East Java Province, namely, Nganjuk Regency, Kediri Regency, Malang Regency and Probolinggo Regency. This selection is based on the shallot planting area in East Java and is chosen as the largest.

2. Selecting the sub-district which is the center of shallot centers from each selected district. Subdistricts are chosen based on the largest shallot producer so that the results are obtained as follows:

Nganjuk Regency > sub-district Rejoso

Kediri Regency > sub-district Badas

Malang Regency > sub-district Ngantang

Probolinggo Regency > sub-district Dringu

3. Selecting the village which is the center of shallots from each selected district. The villages chosen based on the biggest shallot producer and planting are obtained, as follows:

Nganjuk Regency > sub-district Rejoso >Ngadiboyo

Village 
142 Supply Chain Analysis of Shallots Throught Relation Approach. . . . .

\begin{tabular}{lll} 
Kediri Regency & $>$ sub-district Badas & >Sekoto \\
Village & & \\
Malang Regency & $>$ sub-district Ngantang & $>$ Purworejo Village \\
Probolinggo Regency & $>$ sub-district Dringu \\
\multicolumn{1}{c}{$>$ Watuwungkuk village }
\end{tabular}

4. Choosing Farmers Group Association (FGA) to identify the number of populations in the research sites. In each village only have 1 Farmers Group Association, so that the following results are obtained:

Nganjuk Regency = MandiriFarmers Group Association

Kediri Regency = Berkah MulyaFarmers Group Association

Malang Regency = Karya BaktiFarmers Group Association

Probolinggo Regency = Harapan JayaFarmers Group Association

5. Get the number of members of each Farmers Group Association from each Regency, so that the following results are obtained:

Nganjuk Regency $=$ MandiriFarmers Group Association $=1256$ Petani

Kediri Regency $=$ Berkah Mulya Farmers Group Association $=597$ Petani

Malang Regency $=$ Karya Bakti Farmers Group Association $=297$ Petani

Probolinggo Regency $=$ Harapan JayaFarmers Group Association $=240$ Petani

The total number of the Farmers Group Association members is 2390 farmers.

6. The sample distribution corresponds to the size of the selected Farmers

Group Associationmember population with the sample size obtained by the Roscoe formula. The sample size in this research were 200 respondents.

Nganjuk Regency, 1256/2390 x $200=105$ Farmers

Kediri Regency, 597/2390 x $200=50$ Farmers

Malang Regency, 297/2390 x $200=25$ Farmers

Probolinggo Regency, 240/2390 x $200=20$ Farmers 
Table 3. Sampling Techniques

\begin{tabular}{lllllcc}
\hline No & Regencies & $\begin{array}{c}\text { Sub- } \\
\text { Districts }\end{array}$ & Villages & $\begin{array}{c}\text { Farmers } \\
\text { Group } \\
\text { Associati } \\
\text { on }\end{array}$ & $\begin{array}{c}\text { Number of } \\
\text { Farmers } \\
\text { Group } \\
\text { Association }\end{array}$ & $\begin{array}{c}\text { Sam } \\
\text { ples }\end{array}$ \\
\hline 1. & Nganjuk & Rejoso & Ngadiboyo & $\begin{array}{l}\text { Mandiri } \\
\text { Berkah }\end{array}$ & 1256 & 105 \\
2. & Kediri & Badas & Sekoto & $\begin{array}{l}\text { Mulya } \\
\text { Karya } \\
\text { Bakti }\end{array}$ & 597 & 50 \\
3. & Malang & Ngantang & Purworejo & 297 & 25 \\
4. $\begin{array}{l}\text { Proboling } \\
\text { go }\end{array}$ & Dringu & $\begin{array}{l}\text { Watuwung } \\
\text { kuk }\end{array}$ & $\begin{array}{l}\text { Jaya } \\
\text { Jayan }\end{array}$ & 240 & 20 \\
\hline & Total & & & & 2390 & 200 \\
\hline
\end{tabular}

(Source: Processed by Researcher, 2018)

The number of samples and the name of the sample were chosen by random using the Microsoft Excel application. Sample names, number of samples, and Farmers Group Associationobtained from the Department of Agriculture in each region, are included in Microsoft Excel in accordance with those provided by the Agriculture Service. Then, using the RANDBETWEEN function and formula = RANDBETWEEN ( 1 ; number of samples $/$ farmer name) or $==$ RANDBETWEEN (drag from first name to end) - Enter. Then we get a random sample of farmers.

\subsection{Data Collection Technique}

Data collection techniques in this research use primary data and secondary data. Primary data is in the form of data obtained from survey results using questionnaires and supported by interviews to strengthen the results obtained. Secondary data in the form of initial supporting data obtained directly from the Department of Agriculture and Horticulture in each district and data obtained through search engines.

First, data collection techniques with surveys are conducted by a questionnaire method or questionnaire which lists or sets of questions systematically arranged to get answers in the form of opinions from respondents. The questionnaire was used as a research instrument to collect data 
and information from respondents. The questionnaire was designed in such a way as to record and obtain data about the conditions experienced by the respondents themselves.

The questionnaire was arranged according to the data needed by the researcher. The questionnaire is directly closed where alternative answers are available in the questionnaire. The questions that were asked asked the response or perception of the farmers as respondents involved in the shallot supply chain. Questionnaires were distributed to respondents and asked to fill / answer / provide responses to a series or list of questions already listed in the questionnaire. The steps in collecting primary data in this research are as follows:

1. Arranged research instruments, namely research questionnaires covering the characteristics of respondents and items of questions that include each variable used by researchers to conduct research.

2. Conduct testing of research instruments, namely validity and reliability test by distributing questionnaires to 30 initial respondents to find out whether the questionnaire used is valid and reliable. 30 respondents were randomly selected and used as the initial sample of the research.

3. After the research instrument was declared valid and reliable, the research was continued by distributing questionnaires to 200 respondents who had been randomly selected.

4. The distribution of questionnaires is done by door to door to respondents according to the number of samples and according to the name that has been randomized.

5. Respondents filled out the questionnaire accompanied by researchers to be able to understand the questions and answer questions on the questionnaire. This assistance also functions as a deeper data extraction by conducting unstructured interviews with the respondents.

6. After filling out the questionnaire, researchers conducted in-depth interviews in accordance with the answers given by respondents to the filled questionnaire and also some open questions. Open questions are given to the respondent when the researcher obtains data outside of the questionnaire questions that have been prepared, in order to deepen the analysis of the data obtained. This question is also done to confirm to the respondent that the answer given is the right answer according to the opinion of the respondent. 


\subsection{Validity Test}

A valid instrument measures what should be measured and measures what is to be measured (Morissan, 2016: 103). Measuring validity requires careful and careful assessment. Valid or not the instrument can be known from the correlation coefficient. product-moment shows $r \geq 0.30$ (Indrianto, 2009: 77). The validity test aims to determine the level of ability of an indicator in measuring its variables.

\subsection{Reliability Test}

Reliability is an indicator of the level of reliability or trust in a measurement result. A measurement can be said to be reliable or has reliability if it can consistently provide the same answer. A measurement that is totally unreliable means that it cannot measure anything (Morissan, 2016: 99).

The reliability test can use alpha coefficient formula or called alpha crobach $(\alpha)$ with a value greater than 0 . Basic decision making whether a measurement is reliable or not is alpha crobach. If indila alpha crobach is greater than 0.6 , it can be called reliable and vice versa if the alpha crobach value is smaller than 0.6, it is not reliable (Indrianto, 2009: 90). 


\section{RESULTS AND DISCUSSION}

\subsection{Research Hypothesis}

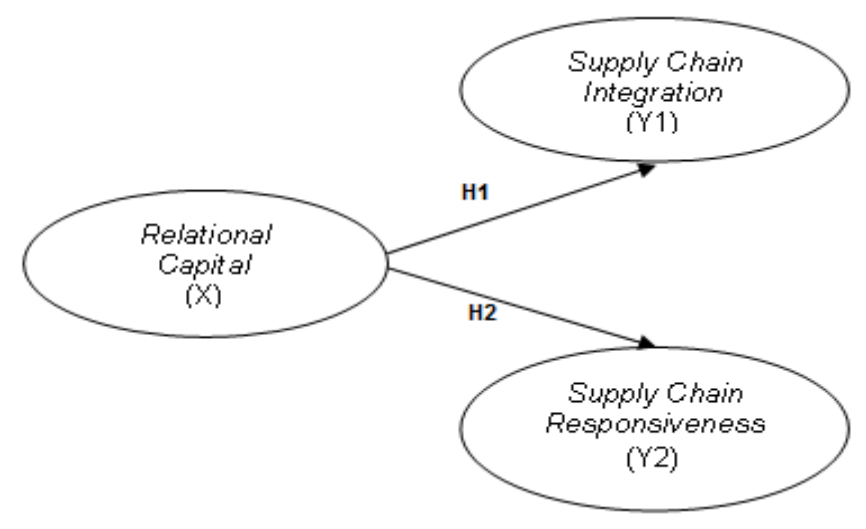

Figure 1. ResearchModel Hypothesis

(Source: Processed by Researcher, 2018)

Based on the background, the formulation of the problem, the purpose of the research and the explanation of the theoretical studies and empirical data of previous research. Then the hypothesis proposed in this research are as follows:

$\mathrm{H}_{1}$ : Relational Capital has an effect on Supply Chain Integration.

$\mathrm{H}_{2}$ : Relational Capital has an effect on Supply Chain Responsiveness.

Tabel 4. Path Analysis Results, Influence (Xtoward $Y_{1}$ and $Y_{2}$ )

\begin{tabular}{cccccc}
\hline $\begin{array}{c}\text { Independent } \\
\text { Variable }\end{array}$ & $\begin{array}{c}\text { Dependent } \\
\text { Variable }\end{array}$ & $\begin{array}{c}\text { Standardized } \\
\text { Beta }\end{array}$ & $\begin{array}{c}\mathbf{t} \\
\text { Count }\end{array}$ & $\begin{array}{c}\text { P- } \\
\text { value }\end{array}$ & Note \\
\hline $\mathrm{X}$ & $\mathrm{Y}_{1}$ & 0,107 & 1,519 & 0,130 & $\begin{array}{c}\text { In } \\
\text { Significant }\end{array}$ \\
$\mathrm{X}$ & $\mathrm{Y}_{2}$ & 0,433 & 6,726 & 0,000 & Significant \\
\hline $\mathrm{R}$ square $\left(\mathrm{R}^{2}\right) 1$ & \multicolumn{2}{c}{$: 0,012$} & & & \\
\hline
\end{tabular}

(Source: Processed by Researcher, 2018)

\subsection{Variable Discussions}

Vol. 28, No. 01 April 2020

(C) Centre for Indonesian Accounting and Management Research

Postgraduate Program, Brawijaya University 
Tabel 5. Variables, Indicators, Items

\begin{tabular}{|c|c|c|c|c|}
\hline No & Variables & Indicators & Items & $\begin{array}{c}\text { Research } \\
\text { ers }\end{array}$ \\
\hline \multirow[t]{4}{*}{1.} & \multirow[t]{4}{*}{$\begin{array}{l}\text { Relational } \\
\text { Capital } \\
\text { (X) }\end{array}$} & Interaction & $\begin{array}{l}\text { a. Trust between parties will help } \\
\text { each other when experiencing } \\
\text { difficulties }\end{array}$ & \multirow{3}{*}{$\begin{array}{l}\text { Veronica } \\
\text { H. Villena } \\
\text { et al. } \\
\text { (2011): }\end{array}$} \\
\hline & & Respect & $\begin{array}{l}\text { a. Between parties believe in the } \\
\text { ability of each party }\end{array}$ & \\
\hline & & Trust & $\begin{array}{l}\text { a. Between parties believe, each } \\
\text { party will keep their mutual } \\
\text { promises }\end{array}$ & \\
\hline & & Cooperation & $\begin{array}{l}\text { a. The existence of togetherness } \\
\text { at work. } \\
\text { b. The existence of mutually } \\
\text { beneficial cooperation with } \\
\text { each other. }\end{array}$ & $\begin{array}{l}\text { Veronica } \\
\text { H. Villena } \\
\text { et al. } \\
(2011) \text { : }\end{array}$ \\
\hline \multirow[t]{2}{*}{2.} & \multirow[t]{2}{*}{$\begin{array}{l}\text { Supply Chain } \\
\text { Integration } \\
\left(\mathrm{Y}_{1}\right)\end{array}$} & $\begin{array}{l}\text { Monitoring } \\
\text { process }\end{array}$ & $\begin{array}{l}\text { a. Together monitor the planting } \\
\text { process } \\
\text { b. Together monitor the harvest } \\
\text { process }\end{array}$ & \multirow[t]{2}{*}{$\begin{array}{l}\text { Huo, } \\
\text { et al. } \\
(2014)\end{array}$} \\
\hline & & $\begin{array}{l}\text { Jointly improve } \\
\text { production }\end{array}$ & $\begin{array}{l}\text { a. There is technical training to } \\
\text { improve quality } \\
\text { b. Marketing expansion }\end{array}$ & \\
\hline \multirow[t]{2}{*}{3.} & \multirow[t]{2}{*}{$\begin{array}{l}\text { Supply Chain } \\
\text { Responsiveness } \\
\left(\mathrm{Y}_{2}\right)\end{array}$} & Capability & $\begin{array}{l}\text { a. Ability to handle requests that } \\
\text { are out of standard. } \\
\text { b. Ability to provide innovative } \\
\text { products }\end{array}$ & \multirow[t]{2}{*}{$\begin{array}{l}\text { Sufian } \\
\text { Qrunfleh, } \\
\text { et al. } \\
(2013)\end{array}$} \\
\hline & & Accuracy & $\begin{array}{l}\text { a. Right in providing customer } \\
\text { requests. } \\
\text { b. On time in harvesting }\end{array}$ & \\
\hline
\end{tabular}

(Source: Processed by Researcher, 2018) 


\subsection{Relational Capital}

The results of the descriptive statistical test showed that the Relational Capital variable consisting of 4 indicators and 5 items had an average value of 3.08 which was categorized as good. This value shows that Relational Capital that exists between shallot farmers and their partners such as suppliers of agricultural production facilities, seeds, pesticides, and consumers is well established even though it has not been maximally established. Relational Capital that is well established is shown in terms of the trust established by farmers and their partners. This belief occurs when farmers and partners experience problems, so both parties will believe that they help each other in overcoming the problems that occur. In addition, farmers and partners alike believe that both parties will keep the mutual promises mutually agreed upon and believe in the workability of each party. Good relations or relations also occur because of the good cooperation between the farmers and their partners and the cooperation occurs quite profitably. It can be concluded that the relations that occur between farmers and their partners have gone quite well, seen from the interactions that occur, the respect between farmers and partners, the existence of the trust, and good cooperation between farmers and their partners.

\subsection{Supply Chain Integration}

Supply Chain Integration $\left(\mathrm{Y}_{1}\right)$ variable which consists of 2 indicators and 4 items has an average value of 3.00 which is categorized sufficient. From the description of the descriptive analysis, it can be seen that between shallot farmers and partners jointly monitor the planting process quite well. farmers and partners jointly monitored the harvest process as being sufficiently categorized and having the lowest average value, farmers participating in technical training organized by partners quite well, and trading partners enough to help expand the marketing of shallots to the end of the consumer's hands. Then it can be concluded that monitoring processes carried out by farmers with partners are categorized as sufficient and jointly improve production by farmers with partners is categorized as sufficient.

\subsection{Supply Chain Responsiveness}

Supply Chain Responsiveness variable (Y2) which consists of 2 indicators and 4 items has an average value of 3.11 which is categorized sufficient. From the description of the descriptive analysis, it can be seen that Vol. 28, No. 01 April 2020

(C) Centre for Indonesian Accounting and Management Research Postgraduate Program, Brawijaya University 
onion farmers are able to respond to the demand from consumers quite well. Farmers are able to provide requests from consumers who are out of standard, able to provide innovations from shallot products, able to provide consumer demand in a timely manner, and be able to harvest in a timely manner. So it can be concluded that farmers have sufficient capability or ability to respond to requests from consumers and are also able to provide these requests with sufficient accuracy so that the supply chain responsiveness of farmers can be categorized sufficiently.

\subsection{Testing the Direct Effects of Relational Capital on Supply Chain Integration}

The results of testing the effect of Relational Capital on Supply Chain Integration can be seen in table 1.2, the research hypothesis tested as follows:

\section{$\mathrm{H}_{1}$ : Relational Capital has a significant effect on Supply Chain Integration.}

The results of path analysis prove the existence of a positive but not significant influence between Relational Capital (X) on Supply Chain Integration $\left(\mathrm{Y}_{1}\right)$. The obtained beta coefficient value of 0.107 which shows that there is a positive influence between Relational Capital to Supply Chain Integration of 0.107 . The P-Value value of 0.130 states that the effect of Relational Capital on Supply Chain Integration is not significant because the Pvalue> 0.05 . So the decision is that $\mathrm{H}_{0}$ is accepted, meaning that the hypothesis that Relational Capital has a significant effect on Supply Chain Integration is rejected. This is because farmers are always harmed by middlemen as suppliers and buyers of shallots because of the information asymmetry received by farmers. The existence of a conflict of interest that occurs between farmers and middlemen, causing information provided to farmers is not fully in accordance with the actual situation, especially in terms of prices. Therefore, farmers sell shallots at a lower price than the market price. In addition, farmers do not have the power to bargain.

Scott (1983) described the relationship that occurs between farmers and middlemen with a description of patron-client relationships, namely relations that occur between farmers and middlemen who have not run well due to differences in interests between the two parties. This is evidenced by several previous studies that said that the relationship between farmers and middlemen 
still has not gone well due to differences in interests (Fuad,2015; Isna, 2014; Rustinsyah, 2011).

Relational is an intangible asset that must be owned and can be developed by business actors because it has high uniqueness, is difficult to imitate, and cannot be replaced (Luthans et. Al (2007); De Saa Perez \& Gracia F. (2002). must have a basis in terms of the trust, friendship, respect, and interaction by the various parties involved (Gelderman et.al, 2016). Relational capital will have an impact on increasing the value of a business being carried out, because it refers to building relationships and networks namely, relationships with customers and suppliers, support for informal relations so that the flow of goods and information can be well integrated so as to reduce the occurrence of asymmetric information (Johanisson, 1998).

\subsection{Testing the Direct Effects of Relational Capital on Supply Chain Responsiveness}

The results of testing the effect of Relational Capital on Supply Chain Responsiveness can be seen in table 1.2, the research hypothesis was tested as follows:

$\mathrm{H}_{2}$ : Relational Capital has an effect on Supply Chain Responsiveness.

The results of the test analysis performed show that there is a positive influence between Relational Capital on Supply Chain Responsiveness which is shown by the value of the beta coefficient which is 0.433 which means that the effect of Relational Capital on Supply Chain Responsiveness is 0.433. The significant value of Relational Capital towards Supply Chain Responsiveness is obtained through P-value. The results of the P-value which is equal to 0,000 which means Relational Capital to Supply Chain Responsiveness has a significant effect because the P-value is $<0.05$. So the decision is that $\mathrm{H}_{0}$ is rejected, meaning that the hypothesis that Relational Capital has a significant effect on Supply Chain Responsiveness is accepted. This means that with a significant influence from Relational Capital to create Supply chain responsiveness to farmers.

Shallots farmers in Nganjuk, Kediri, Malang, and Probolinggo Regencies are able to respond to requests from their partners well so that a responsive supply chain is formed that is quite good. This can be seen from the ability of farmers to deal with requests from diverse buyers, farmers are able to provide innovative products, farmers are able to provide requests from Vol. 28, No. 01 April 2020

(C) Centre for Indonesian Accounting and Management Research Postgraduate Program, Brawijaya University 
customers in a timely manner and harvest shallots on time so that they can be sold to customers with good quality. The good response from farmers is due to the relationship between farmers and their partners, namely agricultural production suppliers such as fertilizers, seeds, and pesticides so that farmers can obtain the best quality agricultural production equipment and on time which has an impact on the success of supplying shallot products quality according to customer demand. The trust of farmers to partners and vice versa causes supply chain responsiveness to be formed and significantly influence each other. This will encourage well-established collaboration to improve business quality (Salvador, Forza, Rungtusanatham, and Choi (2001), and Han, Trienekens, and Onno Omta (2011)). Based on Flamholtz's theory (1973), it was concluded that intangible assets have an important role to play in creating appropriate relationships and increasing responsiveness to the needs of customers and partners so as to create a competitive advantage in various sectors including the agricultural sector. Relational capital (RC) includes organizational relations with outside parties such as customer loyalty, goodwill, supplier relations (IFAC, 1998: 9), and relations with the community (Moon and Kym, 2006). CIMA (2005: 2) states that relational capital as all resources related to the company's external relations - with customers, suppliers, or partners in research and development through the ability to respond to developments that occur.

\section{CONCLUSIONS}

1. Relational Capital is well established between farmers and suppliers, which will not affect or increase shallot supply chain integration in Nganjuk, Kediri, Malang, and Probolinggo districts. The existence of an integrative supply chain is influenced insignificantly by relational capital because relational capital is something that farmers have done before the supply chain is created, even though the relationships formed still do not go well because of various problems that occur as described by previous researchers.

2. The existence of Relational Capital in farmers will create Supply chain responsiveness to farmers. The trust of farmers to partners and vice versa causes supply chain responsiveness to be formed and significantly influence each other. The trust given by farmers to partners and partners to farmers makes farmers and partners able to work together quite well so that it affects the responsiveness of each party.

Vol. 28, No. 01 April 2020

Centre for Indonesian Accounting and Management Research Postgraduate Program, Brawijaya University 


\section{SUGGESTIONS}

1. The government needs to implement a policy that regulates the selling price of farmers to middlemen so that farmers experience profits when selling their crops.

2. Farmers need to establish good relationships with all partners, both the government as policymakers, saprotan suppliers and red onion traders or buyers to create an integrated supply chain.

3. For the next researcher, it is expected to use all dimensions on the variable social capital, namely cognitive, structural and relational dimensions, and can add other variables included in the supply chain management activity component as a good supply chain management activity. For example information sharing, information quality, postponement, agreed on vision and goals, etc. as additional variables to support analysis.

4. The object of research in this research was only carried out on shallot farmers so that the next researcher is expected to be able to examine not only farmers but also suppliers of drugs, seeds, saprotants and collectors, traders so that the information obtained will be even wider. 


\section{REFERENCES}

\section{Buku}

Assauri, Sofjan, 2011. Strategic Management, Sustainable Competitive Advantage. Jakarta.

Anatan, Lina. Ellitan, Lena, 2008. Supply Chain ManagementTeori dan Aplikasi. CV.

Alfabeta:Bandung

Conway, F., Kaganova, O., \& McKellar, J. (2006). A "Composite Image" of Central

Government Asset Management Reforms. Managing government property assets: International experiences, 125 .

Flamholtz, Eric. (1973). A model for human resource valuation: A stochastic process with

service rewards, The Accounting Review 253-267.

Gunawan, Herry. 2014. Pengantar Transportasi dan Logistik. Jakarta: RajaGrafindo Persada.

Indrianto dan Supomo. 2009. Metode Penelitian Bisnis. Edisi Pertama. Yogyakarta: BPFE.

Lummus R.J, R.R., Duclos, L.K., Vokurka 2003. A conceptual model of supply chain flexibility.

Industrial Management \& Data Systems 103, 446-456

Luthans, Fred, Youssef, Carolyn M., Avolio, Bruce J., 2007. Psychological Capital : Developing

The Human Competitive Edge. New York : Oxford Uiversity Press

Maghfiroh, Marimin Nurul, 2010. Aplikasi Teknik Pengambilan Keputusan Dalam Manajemen Rantai

Pasok. Bogor: PT. Penerbit IPB Press.

Vol. 28, No. 01 April 2020

(C) Centre for Indonesian Accounting and Management Research Postgraduate Program, Brawijaya University 
Mata, F., W. Fuerst, And J. Barney, 1995. Information Technology And Sustained Competitive

Advantage: A Resource-Based Analysis. MIS Quarterly 19(4), 487-505.

Moeheriono. 2012. Pengukuran Kinerja Berbasis Kompetensi. Jakarta: Raja Grafindo Persada.

Morissan. 2012. Metode Penelitian Survei. Jakarta: Prenada Media Group.

Mubyarto, 1989. Pengantar Ekonomi Pertanian. LP3ES. Jakarta

Nazir, Mohammad. 2014. Metode Penelitian Bisnis. Bogor: Ghalia Indo.

Nurmala, T. 2012. Pengantar Ilmu Pertanian. Yogyakarta : Graha Ilmu.

Rustinsyah. 2011. Hubungan Patron Klien Di Kalangan Petani Desa Kebonrejo. Jurnal. Vol.24, No.2.

Surabaya. Universitas Airlangga. Hal 176-182.

Scott, JC. (1983). Moral Ekonomi Petani (Cetakan Kedua). Jakarta: LP3S.

Sugiyono. 2010. Metode Penelitian Pendidikan Pendekatan Kuantitatif, Kualitatif, Dan R\&D.

Bandung: Alfabeta

Thatte, Ashish AView Profile; Rao, Subba SView Profile; Ragu-Nathan, T S. 2013. Impact Of

SCM Practices Of A Firm On Supply chain Responsiveness And Competitive Advantage Of A Firm. The Journal of Applied Business Resesarch Vol.29 No.2.

Turban, E., King, D., Mckay, J., Marshall, P., Lee, J., \& Viehland, D. 2008. Electronic Commerce 2008

A Managerial Perspective. New Jersey: Pearson Education, Inc.

Van Der Vorst J. G. A. J., 2004.Supply Chain Management: Theory And Practices, The Emerging

World Of Chains \& Networks. Elsevier, Hoofd-Stuk 2.1, Wageningen.

Vol. 28, No. 01 April 2020

(C) Centre for Indonesian Accounting and Management Research

Postgraduate Program, Brawijaya University 
Journal

Ageron B, Gunasekaran A, Spalanzani A., 2011. Sustainable Supply Management: An Empirical Study.

Int. J. Production Economics, Article In Press.

Bailey WC, Norina L, Cassavant K. 2002. The Use of Supply Chain. Management to Increase Exports

of Agricultural Products. Proceeding of the 5th International Conference on Chain and Network in Agribusiness and The Food Industry (eds. J.H. Trienekens and S.W.F. Omta). 410-421. Wageningen, The Netherlands.

Barney, J.B., 1991. Firm Resources And Sustained Competitive Advantage. Journal Of Management.

Vol. 17: Pg. 99-120.

Centinkaya, B., Cuthbertson, R., Ewer, G., Klaas-Wissing, T., Piotrowicz, Dan W., Tyssen, C. 2011.

Sustainable Supply Chain Management. Springer. Germany.

Firdaussy Y. 2012. Analisa Integrasi Pasar dan Transmisi Harga Beras Petani Konsumen di Indonesia.

Jakarta (ID): Fakultas Ekonomi, Universitas Indonesia.

Flynn, B.B., Huo, B. \& Zhao, X., 2010. The Impact Of Supply Chain Integration On Performance: A

Contingency And Configuration Approach. Journal Of Operations Management, 28(1), Pp.58-71.

Fuad, Zainul, Aenurofik Dan Rosyid, 2015. Belenggu Tengkulak Atas Pembudidaya Lele: Relasi

Patron-Klien Budidaya Lele Di Wono Tunggal Jawa Tengah. Jurnal Hukum Islam (JHI), 13(2): 88-98.

Frohlich, M. T. \& Westbrook, R., 2001. Arcs Of Integration: An International Study Of Supply Chain

Strategies. Journal Of Operations Management, 19, Pp. 185-200.

Vol. 28, No. 01 April 2020

(C) Centre for Indonesian Accounting and Management Research Postgraduate Program, Brawijaya University 
Gelderman, Cees J., Janjaap Semeijn, Patrique P. Mertschuweit, 2016. The Impact Of Social Capital

And Technological Uncertainty On Strategic Performance: The Supplier Perspective. Journal Of Purchasing \& Supply Management.

Ghai S. 2012. Value Chain Financing: Strategy Towards Augmenting Grwoth in Agriculture Sector in

India. Journal of Economics and Sustainable Development. 3(10).

Ibrahim Siddig Balal, Abdelsalam Adam Hamid, 2012, Supply Chain Management Practices and

Supply Chain Performance Effectiveness, International Journal of Science and Research (IJSR),p.187-195

Jezghani F, Moghaddasi R, Yazdani S, Mohamadinejad A. 2011. Price Transmission Mechanism

in the Iranian Rice Market. International Journal of Agricultural Science and Research. 2(4).

Johanisson, B., 1998. Personal Networks In Emerging Knowledge-Based Firms: Spatial And

Functional Patterns. Entrepreneurship And Regional Development, 10. 297-312

Moon, Y. J. and Kym, H. G. (2006), A Model for the Value of Intellectual Capital. Canadian

Journal of Administrative Sciences, 23: 253-269.

Moran, Florencia., Palmer, David., Borstoff, Patricia C. 2007. An exploratory analysis of the

relationship between organizational culture, regional culture, causal ambiguity and competitive advantage in an international setting. Journal of International Business Research, Vol. 6, No. 1

Nashika, Isna Ainun, 2014. Relasi Petani Gurem Dengan Tengkulak Sebagai Pertukaran Sosial

Petani Di Kabupaten Banyuwangi. Skripsi Jurusan Sosiologi, Fakultas Ilmu Sosial Dan Politik, Universitas Negeri Jember

Vol. 28, No. 01 April 2020

(C) Centre for Indonesian Accounting and Management Research Postgraduate Program, Brawijaya University 
Ngah, Rohana And Ibrahim, Abdul Razak, 2009. The Relationship Of Intellectual Capital,

Innovation Dan Organizational Performance: A Preliminary Study In Malaysian SMEs. International Journal Of Management Innovation Systems Vol. 1 No. 1:E1, Pp. 1-13.

Peteraf, M. A. 1993. The Corner Stones Of Competitive Advantage: A Resource-Based View.

Strategic Management Journal , 179-191

Rasoki T, Fariyanti A, Rifin A. 2016. Pembandingan Efisiensi Pemasaran Bawang Merah Konsumsi

dan Benih di Kabupaten Brebes, Provinsi Jawa Tengah. Jurnal Agro EKonomi. 34(2): 145-160

Saa-Perez \& Garcia-Falcon. 2002. A Resource-Based View Of Human Resource Management And

Organizational Capabilities Development. International Journal Of Human Resource Management, Vol. 13, No.1, PP. 123-140

Salvador, Fabrizio., Cipriano Forza, Manus Rungtusanatham, Thomas Y. Choi. 2001. Supply Chain

Interactions And Time-Related Performances: An Operations Management Perspective. International Journal Of Operations \& Production Management, Vol. 21 No. 4, 2001, Pp. 461-475.

Schoenherr, T. \& Swink, M., 2012. Revisiting The Arcs Of Integration: CrossValidations And

Extensions. Journal Of Operations Management, 30(2), Pp.99-115

Sefiana, Eka. 2009. Pengaruh Penerapan Corporate Governance Terhadap Manajemen Laba Pada

Perusahaan Manufaktur Yang Go Public di BEI. Jurnal Riset AkuntansiFakultas Ekonomi-Universitas Gunadarma, No. 2 Vol IX.

Setiawan, Ahmad Ikhwan Dan Reza Rahardian. 2005. Pengaruh Pola Integrasi Supply Chain 
Management Terhadap Performa Perusahaan Pada Industri Jasa Makanan Di Surakarta. Jurnal Bisnis \& Manajemen. Vol 05, No.1

Seuring S. 2012. A Review Of Modeling Approaches For Sustainable Supply Chain Management.

Decision Support Systems, Article In Press

Sufian Qrunfleh And Monideepa Tarafdar. 2013. Lean And Agile Supply Chain Strategies And

Supply Chain Responsiveness: The Role Of Strategic Supplier Partnership And Postponement. Department Of Computer Information Systems, Eastern Michigan University, Ypsilanti, Michigan, USA,Department Of Management Science, Lancaster University, Lancaster, UK. Supply Chain Management: An International Journal $18 / 6$ (2013) 571-582

Veronica H. Villenaa,*, Elena Revilla A, Thomas Y. Choib. 2010.The Dark Side Of Buyer-

Supplier Relationships: A Social Capital Perspective. Department Of Operation And Technology Management, IE Business School, USA. Journal Of Operations Management.

Welbourne, T.M., 2007. Employee Engagement : Beyond The Fad And Into The Executive

Suite. Executive Forum.

Wernerfelt, B. 1984. A Resource-Based View Of The Firm. Strategic Management Journal , 171-180.

Woods, E.J. 2004. Supply chain management: understanding the concept and its implication in

developing countries. In Agriproduct supply chain management in developing countries. ACIAR Proceedings No. 119. Australian Center for International Agriculture Research.

Wong, H., Potter, A., \& Naim, M. (2011). Evaluation of postponement in the soluble coffee 
supply chain: A case study. International Journal of Production Economics, $\quad$ 131(1), 355-364. doi.org/10.1016/j.ijpe.2010.08.015

Yeung, Jeff HoiYan., Willem Selen.,Min Zhang, Ph.D.,Baofeng Huo. 2009. The Effects Of Trust

And Coercive Power On Supplier Integration. International Journal of Production Economics .

\section{Web}

Badan Pusat Statistik. 2018. Pertumbuhan Ekonomi Indonesia Triwulan I-2018 No. 40/05/Th.XXI.

Pusat Pengkajian Perdagangan Dalam Negeri Badan Pengkajian Dan Pengembangan Perdagangan

Kementerian Perdagangan Republik Indonesia. 2017. Analisis Perkembangan Harga Bahan Pangan Pokok Di Pasar Domestik Dan Internasional

Badan Pusat Statistik. 2015. Katalog. Distribusi Perdagangan Komoditas Bawang Merah Indonesia

Pusat Data Dan Sistem Informasi Pertanian Sekretariat Jenderal - Kementerian Pertanian. 2015.

\section{OUTLOOK BAWANG MERAH}

Kementrian Pertanian Republik Indonesia. 2015. Outlook Komoditi Bawang Merah 2015. (Online) Di

Unduh Dari: Http ://Epublikasi.Setjen.Pertanian.Go.Id /Epublikasi/Outlook/2015/Outlook_Horti/Outlook_Bawangmerah_2013 /Files/Assets/Downloads/Publication.Pdf ( 3 Oktober 2018)

Tim Pemantauan Dan Pengendalian Inflasi (TPI) Kelompok Kerja Nasional Tim Pengendalian

Inflasi Daerah (Pokjanas TPID). 2016. Inflasi 2016 Cukup Rendah Dan Berada Dalam Batas Bawah Sasaran Inflasi Bank Indonesia. Artikel 
160 Supply Chain Analysis of Shallots Throught Relation Approach. . . . .

Direktorat Jenderal Perdagangan Dalam Negeri Kementerian Perdagangan. Profil Komoditas

Barang Kebutuhan Pokok Dan Barang Penting Komoditas Bawang. 2016

Https://Farming.Id/Kondisi-Pertanian-Indonesia-Apakah-Bisa-Maju/

Https://Www.Cnnindonesia.Com/Ekonomi/20170330191343-92-

203859/Lahan-Pertanian-Di-Indonesia-Makin-Tak-Menarik-Bagi-Pekerja

Https://Ekonomi.Kompas.Com/Read/2017/09/30/132000326/Sektor-PertanianDan-Citra-Indonesia-Di-Mata-Dunia.

Https://Ekonomi.Kompas.Com/Read/2017/03/30/204932226/Tiga.Masalah.Uta ma.Sektor.Pertanian.Nasional.Apa.Saja..

Https://Ekonomi.Kompas.Com/Read/2017/12/09/132457826/Ikatan-AlumniFakultas-Pertanian-Usu-Ungkap-5-Masalah-Petani-Indonesia.

Https://Ekonomi.Kompas.Com/Read/2017/03/30/204932226/Tiga.Masalah.Uta ma.Sektor.Pertanian.Nasional.Apa.Saja.)

Https://Ekonomi.Kompas.Com/Read/2017/12/09/132457826/Ikatan-AlumniFakultas-Pertanian-Usu-Ungkap-5-Masalah-Petani-Indonesia

Http://Www.Litbang.Pertanian.Go.Id/Special/Komoditas/B3bawang

Https://Ekonomi.Kompas.Com/Read/2018/07/10/181700326/Indonesia-

Kembali-Ekspor-Bawang-Merah-Ke-Singapura

Http://Www.Fao.Org/Faostat/En/\#Country

Vol. 28, No. 01 April 2020

(C) Centre for Indonesian Accounting and Management Research

Postgraduate Program, Brawijaya University 